DOI: $10.17805 / \mathrm{ggz} .2020 .6 .2$

\title{
Наследие К. Марло в художественной литературе XIX-XXI вв.: основные контексты
}

\author{
Б. Н. Гайдин
}

Московский гуманитарный университет

В статье представлены примеры использования фигуры Кристофера Марло, а также отсылок к его творчеству в произведениях англоязычных и русскоязычных авторов. Выявлены и охарактеризованы основные тенденции рецепции образа поэта и драматурга и его сочинений, а также предложень некоторые выводы о том, как трансформируются и видоизменяются многочисленные мифы, связанные с биографией «загадочного» современника Шекспира.

Ключевые слова: К. Марло; У. Шекспир; современники Шекспира; художественная литература; современная литература; современная культура

\section{The Legacy of C. Marlowe in the Fiction of the 19th-21st Centuries: The Main Contexts}

B. N. Gaydin

Moscow University for the Humanities

The article presents examples of the appropriation of the image of Christopher Marlowe, as well as references to his heritage in the works of English and Russian writers. The author reveals and characterizes the main trends in the reception of the icon of the poet and playwright and his works. The scholar draws some conclusions on how numerous myths associated with the biography of the "mysterious" contemporary of Shakespeare transform and modify.

Keywords: C. Marlowe; W. Shakespeare; Shakespeare's contemporaries; fiction; contemporary literature; contemporary culture

\footnotetext{
* Статья подготовлена в рамках проекта «Кристофер Марло и его творчество в русской и мировой культуре: междисциплинарный взгляд» при финансовой поддержке РФФИ (грант № 18-012-00679).

The article was prepared within the framework of the project "Christopher Marlowe and His Literary Heritage in Russian and World Culture: An Interdisciplinary Look" with financial support from the Russian Foundation for Basic Research (grant no. 18-012-00679).
} 


\section{ВВЕДЕНИЕ}

Творчество Кристофера Марло и фигура самого драматурга, хотя и не могут соперничать с влиянием шекспировского наследия и культа Шекспира (Луков, Захаров, 2008; Захаров, Луков, 2011), тем не менее находят отражение в современной художественной литературе. Многочисленные мифы о поэте, таинственная гибель в возрасте 29 лет в Детфорде, различные конспирологические теории, в том числе и марловианская версия пресловутого «шекспировского вопроса» (см., например: Иванов, Макаров, Радлов, 2018) и т. д. - все это, безусловно, благодатная почва для создания художественных произведений, лишь отчасти основанных на исторических фактах.

В данном статье мы приведем примеры, выявим и охарактеризуем основные тенденции рецепции Марло и его сочинений в английской и русской художественной литературе XIX-XXI столетий.

\section{ОБРАЗ К. МАРЛО И ЕГО НАСЛЕДИЕ В АНГЛОЯЗЫЧНОЙ ЛИТЕРАТУРЕ ХІХ-ХХІ ВВ.}

Самым первым художественным произведением, в котором Марло стал главным героем, считается роман Уилбура Глисона Зиглера (Цайглера; Wilbur Gleason Zeigler, 1857-1923) «Это был Марло: история трехсотлетнего секрета» ("It Was Marlowe: A Story of the Secret of Three Centuries"), который вышел в 1895 г. В предисловии писатель выдвигает предположение, что Марло смог избежать гибели в 1593 г., убив мужа своей возлюбленной, выдал его тело за свое и подался в бега. Сам же драматург был, возможно, убит Беном Джонсоном спустя 5 лет, в 1598 г. (Джонсон на самом деле убил в тот год актера Габриэля Спенсера). Таким образом, некоторые произведения, приписываемые Шекспиру, по мнению писателя, принадлежат перу Марло. На этой гипотезе Зиглер и строит художественное повествование своего сочинения, положив начало т. н. марловианской теории (см. подробнее: Гайдин, 2020).

В 1932 г. вышел в свет исторический роман австралийского писателя и сценариста Филипа Линдсейя (Philip Lindsay; 1906-1958) «Один кинжал на двоих: злополучная история Кристофера Марло» (“One Dagger for Two: The Hapless Tale of Christopher Marlowe”), повествующий о последнем годе жизни драматурга. Перу Линдсейя принадлежат также исторические романы, к примеру, о пятой жене Генриха VIII Кэтрин Говард, любовнице Эдуарда IV Джейн Шор, урожденной Ламберт (которая, кстати, упоминается в «Ричарде III» Шекспира, выступает в качестве персонажа анонимной пьесы «Истинная трагедия Ричарда III» и исторической хроники «Эдуард IV», приписываемой Томасу Хейвуду). Линдсей также является автором биографий Ричарда III и Генриха V. Он выступал консультантом кинокартины 1933 г. «Частная жизнь 
Генриха VIII» режиссера Александра Корды, которая получила две премии «Оскар» и даже была представлена на Московском кинофестивале в 1935 г. Т. е. это был достаточно много знающий и хорошо разбирающийся в данном историческом периоде литератор.

В романе «Один кинжал на двоих», который предварен цитатой из «Фауста», мы встречаем драматурга в период работы над трагедией «Эдуард II». Он изображен убежденным атеистом, картежником, повесой и любителем вина. Миф о богоборчестве Марло - один из самых частотных в произведениях, в которых он присутствует.

Интересно, что в романе писателя убивают в таверне вовсе не из-за спора о счете (о чем гласит официальное заключение властей), а из-за таинственной женщины, в которую он влюблен (как, впрочем, и в жену своего покровителя Томаса Уолсингэма, который, как известно, действительно кроме Марло поддерживал таких поэтов, как Томас Нэш, Джордж Чапмен, Томас Уотсон). Именно таинственной незнакомке герой романа Марло посвящает свое пасторальное стихотворение «Влюбленный пастух своей возлюбленной» (“The Passionate Shepherd to His Love"; опубл. 1599).

Исторический роман «Введите шпиона: двойная жизнь Кристофера Марло» ("Enter a Spy: The Double Life of Christopher Marlowe") британского актёра чешского происхождения Герберта Лома (Herbert Lom; 1917-2012), который известен, например, по роли инспектора Шарля Дрейфуса в серии фильмов «Розовая пантера». Книга была впервые опубликована в 1978 г. Интересно, что права на экранизацию этого произведения (как и второго исторического романа Лома о Великой французской революции) были выкуплены, но пока роман не был экранизирован.

«Введите шпиона» повествует о романтической любовной связи Марло с Франсес Уолсингем, графиней Эссекс (Frances Walsingham, Countess of Essex), дочерью государственного секретаря, члена Тайного совета, начальника разведки и контрразведки Англии сэра Фрэнсиса Уолсингема (Sir Francis Walsingham), а также супругой сначала поэта сэра Филиппа Сидни (Sir Philip Sidney), затем фаворита Елизаветы I Роберта Деверё, 2-го графа Эссекса (Robert Devereux, 2nd Earl of Essex). Спустя два года после казни последнего она вышла замуж за Ричарда Берка, 4-го графа Кланрикард (Richard Burke, 4th Earl of Clanricarde).

В предисловии к роману Г. Лом пишет, что начал интересоваться елизаветинской эпохой со студенческих лет в Кембридже: «Я был увлечен периодом, когда борьба между католиками и протестантами имела влияние на всю Европу так же, как холодная война оказывает значительное влияние на наши 
жизни сегодня» ${ }^{1}$ (Lom, 1978: ix; здесь и далее пер. наш. - Б. Г.). По его мнению, Марло - «один из самых молодых, но самых сведущих политических интриганов, двойных шпионов и гениальных трагических поэтов», который стал его «героем задолго до того, как антигерои сегодняшнего дня “почувствовали себе дома" и захватили воображение публики» ${ }^{2}$ (ibid.). Писатель так охарактеризовал свою работу: «Это история, которая могла иметь место» ${ }^{3}$ (ibid.: 23 ; курсив источника. - Б. Г.). Отметим тот факт, что умирает Марло с именем Господа на устах.

В выпуске «Мужчины счастливой судьбы» ("Men of Good Fortune"; 1990) комикса «Песочный человек» (“The Sandman”) Нила Гаймана (Neil Gaiman; род. 1960) Марло встречает Шекспира, и они обсуждают его «Доктора Фауста», при этом Шекспир прямо заявляет, что уступает Марло в таланте.

Роман Энтони Берджесса (Anthony Burgess; 1917-1993) «Мертвец в Дептфорде» (“А Dead Man in Deptford”), изданный в 1993 г., получил довольно большую известность. Здесь Марло - агент Ее Величества, работающий на Френсиса Уолсингема, влюбленный в его кузена Томаса Уолсингема. По всей видимости, именно это произведение оказало некоторое влияние на других писателей и сценаристов, которые чаще стали обыгрывать миф о нетрадиционной сексуальной ориентации Марло в своих сочинениях (см., например: Смыслова, 2020).

Следующий пример - написанный Гарри Тёртлдавом (Harry Turtledove; род. 1949) в жанре «альтернативная история» роман «Подчиненная Британия» (“Ruled Britannia", 2002), в котором читателю предлагается версия, что было бы, если Испанская армада одержала в 1588 г. победу. Марло (как и Шекспир) представлен здесь как ярый борец за освобождение родины от власти короля Филиппа II и является второстепенным персонажем. История рассказывается от лица Шекспира и испанского драматурга Лопе де Веги. Шекспиру заказывают сразу две пьесы: одну заговорщики, а другую испанцы. Англичане просят использовать миф о королеве бриттского племени иценов Боудикки, которая восстала против римлян, вторгнувшихся в Британию. Таким образом они надеются поднять народные волнения, освободить Елизавету I из Тауэра и изгнать чужеземцев. В результате этот план срабатывает: Елизавета возвращается на трон, в благодарность дарует Шекспиру рыцарское звание, позволяет развестись с нелюбимой женой Энн и даже поставить пьесу «Король Филипп»,

\footnotetext{
1 "I was fascinated by a period in which the Protestant-Catholic struggle dominated Europe in the way that the cold-war dominates our lives today".

2 "One of the youngest but most expert string-pullers, double spy and tragic poet of genius, Kit Marlowe, became my hero long before today's anti-heroes 'came in from the cold' and captured the imagination of the public".

3 "It is history as it might have been".
} 
написанную по заказу испанцев. В конце романа Шекспир ходатайствует об освобождении Лопе де Веги.

Роман «Тамерлан должен умереть» (“Tamburlaine Must Die”, 2004) Луизы Уэлш (Louise Welsh; род. 1965) повествует о последних днях жизни Марло. Интересно, что это произведение написано от первого лица, т. е. представляет собой своеобразный дневник драматурга.

В романе «Историческая пьеса: жизни и дальнейшая судьба Кристофера Марло» ("History Play: The Lives and After-life of Christopher Marlowe", 2005) Родни Болта (Rodney Bolt) использован миф о том, что Марло сымитировал свою смерть и покинул Туманный Альбион.

В серии романов Элизабет Беа (Elizabeth Bear; род. 1971) «Эпоха Прометея» (“The Promethean Age”, 2006-2013) Марло - любовник Шекспира, которому последний посвятил многие из своих сонетов. Марло также не погибает в 1593 г., а отправляется в Сказочную страну (Faerie), где влюбляется в ведьму Морнан ле Фей (Morgan le Fay).

В серии детективных романов (“The Kit Marlowe Series”, изд. с 2011 г.) Мейриона Джеймса Tроу (Meirion James Trow; род. 1949) Марло - вновь шпион и агент сэра Фрэнсиса Уолсингема.

В романе в стихах «Записки Марло» (“The Marlowe Papers”, 2012) Роз Барбер (Ros Barber; род. 1964) Марло размышляет о своей судьбе, вспоминает о том, как смог сфабриковать свою смерть и о том, что его пьесы затем приписали Шекспиру.

Марло в образе демона появляется в историко-фантастическом романе «Тени ночи» (“Shadow of Night”, 2012) Деборы Харкнесс (Deborah Harkness; род. 1965) — второй книги трилогии «Все души» (“All Souls”).

Книга «Этот Марло» (“This Marlowe”, 2016) Мишелль Батлер Халлетт (Michelle Butler Hallett) повествует о роли Томаса Кида в судьбе Марло, их дружбе и событиям, которые привели к гибели драматурга-вольнодумца.

В качестве второстепенного персонажа Марло появляется в романе «Взлет и падение Д.О.Д.О.» (“The Rise and Fall of D.O.D.O.”, 2017) Нила Стивенсона (Neal Stephenson; род. 1959) и Николь Галланд (Nicole Galland; род. 1965). Здесь опять же Марло - агент, разыгравший свою смерть для конспирации своей шпионской деятельности.

\section{ОБРАЗ К. МАРЛО И ЕГО НАСЛЕДИЕ В РУССКОЯЗЫЧНОЙ ЛИТЕРАТУРЕ ХХ-ХХІ ВВ.}

На данный момент нам удалось найти 10 русскоязычных художественных произведений, которые как-то связаны с фигурой К. Марло: цикл «Три новеллы о Шекспире» Ю. О. Домбровского (опубл. 1969); рассказ «Лондон- 
ская трагедия» А. Т. Губина (изд. 1974; книга «Афина Паллада: двенадцать рассказов»); новелла «Надгробье Кристофера Марло» Ю. М. Нагибина (1975?); сонет «Кристофер Марло, или Гадание на цветах» Н. Н. Матвеевой (1994); фантастическая повесть «Дело об архиве Уильяма Шекспира» А. А. Калугина (2002); рассказы «Зависть на века. Легенда о докторе Фаусте», «Он слишком много знал. Шпион Марло» Кира Булычёва (книга «Тайны Нового времени», 2005); книга «Круг чудес и превращений, или Мир вокруг “Глобуса"» Е. И. Парнова (2005); детектив «Шарада Шекспира» Н. А. Солнцевой (2007); роман «Чиста Английское убийство» К. Ю. Еськова (2018), повесть «Мастерская Шекспира» Б. А. Голлера (2019).

Рассмотрим некоторые из них более подробно.

В новелле «Смуглая леди» из цикла «Три новеллы о Шекспире» Ю. О. Домбровского (1909-1978) находим упоминание о гибели Марло от ножевого ранения в трактире; в новелле «Вторая по качеству кровать» указан возраст, когда Марло скоропостижно и трагически ушел из жизни, будучи, как и Роберт Грин, «пьяницей и пропащей душой» ${ }^{4}$; наконец, в «Королевском рескрипте» опять же есть краткое упоминание об обстоятельствах убийства драматурга (см.: Рябова, Жаткин, 2014).

Действие новеллы «Надгробье Кристофера Марло» (1975?) Ю. М. Нагибина (1920-1994) происходит в Детфорде, куда в 1593 г. отправились многие лондонцы, спасаясь от черной чумы. К. Марло обсуждает с аристократом по имени Кеннингхем влияние эпидемии на жизнь в Англии (в том числе на публичные дома), отвечает на вопрос, почему уехал из Лондона, последовав за актерами своего театра, поскольку «служители Мельпомены осторожны и пугливы, как олени» (Нагибин, 1983: 217). Марло заканчивает новую пьесу и не может жить без театра. Кеннингхем, «черный председатель чумных пиров» (там же: 218), нарушил клятву не покидать столицу и уехал, поскольку таково было желание его возлюбленной Мери. Молодой аристократ, ценитель литературы, развенчивает слухи об оргиях на чумных пирах: «Кто-то пел, кто-то читал стихи, а кто-то беззвучно плакал. Порой смех сменялся стоном, шутка — криком боли. Но распускаться никому не дозволялось. И тень вечности склонялась над нашим столом. Тон задавали - важность, достоинство, сосредоточенность» (там же: 219). Для Марло такие пиры - «скука».

Марло Нагибина не верит в загробную жизнь, по всей видимости, исповедуя пантеизм: «Он не соблазнялся раем, не боялся ада. Он верил в Океан. Там были бури и постигаемая беспредельность. Там, в глубине зеленых вод,

\footnotetext{
4 «Ваш возлюбленный Марло и Грин были пьяницы и пропащие души. Поэтому одного зарезали, а другой сгорел от вина. А вы хозяин, джентльмен и благоразумный человек» (Домбровский, 1992: 176).
} 
обитали загадочные существа, незнаемые формы жизни и, быть может, потонувшие миры. <..> Там возбуждался человеческий дух, подымался до подвига, безоглядного риска, разбоя, убийства. Но это - пена, сметаемая ветром с тяжелых океанских волн. А сам Океан, неукротимый, беспредельный, чист и безгрешен. Омыть душу Океаном, что может быть прекраснее на свете!» (там же). Океан - вот, что притягивает нагибинского Марло. Он не исключает, что когда-нибудь уйдет в моряки, поскольку иногда ни творчество, ни театр, ни жизненные удовольствия не приносят ему искомого «утоления».

По мнению Марло, главное для писателя — «верить в то, что ты пишешь» (там же: 220). Далее они обсуждают «Фауста» драматурга. Кеннингхем замечает, что герой Марло, «в отличие от своего прообраза, выбирает не бога и вечное спасение, а Елену и вечность мига наслаждения. Значит, все-таки главное - любимая женщина?» (там же). Из текста становится ясно, что Марло любит женское общество, готов отдать жизнь за каждую из любимых в конкретный момент, однако смерть не приходит, а жизненный поток несет поэта дальше.

Далее Кеннингхем упоминает пьесу «Тит Андроник», идущую в «Глобусе». Марло говорит, что ему действительно приписывают авторство этой трагедии, но на самом деле ее написал «некто Шекспир из Стратфорда на Эвоне» (там же: 223). Интересно, что драматург хвалит своего начинающего коллегу: «Клянусь, Кеннингхем, о нас вспомнят только потому, что мы были современниками этого парня» (там же). На это Кеннингхем отвечает, что хотел бы остаться «современником Марло». Кит приглашает друга и его возлюбленную в театр на постановку своего «Эдуарда II».

Марло отправляется на поиски своей любовницы Катарины, которую находит только «в задних комнатах третьего по счету трактира» в обществе молодого человека по имени Фрэнсис Арчер, которого Марло причисляет к «скучной и докучной когорте поклонников» (там же). Оказывается, что драматург действительно любит ее в отличие от других многочисленных девиц легкого поведения и дам из высшего общества. В припадке ревности он с кинжалом бросается на «мерзавца», который восхищался творчеством и славой Марло и сам некогда хотел стать актером и литератором, но из-за угрозы отца лишить его наследства отказался от этого пути. Именно поэтому Арчер и решил «отбить» у своего кумира любовницу, чтобы хотя бы таким образом приблизиться к нему.

Арчер не ожидал такого развития событий и из-за инстинкта самосохранения ударил Марло по локтю так, что кинжал попадает поэту прямо в глаз, пронзив мозг: «Океан нахлынул и поглотил Марло» (там же: 227). 
Таким образом, Ю. М. Нагибин также обыгрывает миф о том, что драматург погиб в драке из-за женщины, а вовсе не в ссоре из-за счета в таверне. Писатель сообщает нам о дальнейшей судьбе Арчера. Суд оправдывает его, учтя показания свидетелей о том, что все произошло в порядке самообороны: «В конце концов Марло был всего лишь актеришкой и стихоплетом, а Фрэнсис Арчер - богачом и эсквайром» (там же). Убийца Марло разочарован таким развитием событий, отправляется на поиски могилы поэта, которого церковь запретила хоронить в пределах кладбища. На могильной табличке Арчер обозначен как убийца поэта: «Бедный Кеннингхем хотел навечно пригвоздить убийцу к позорному столбу, но даровал ему бессмертие» (там же: 228). Арчер плачет от счастья. Все оставшуюся жизнь он посвятил уходу за могилой своего кумира, на которой было увековечено и его имя.

Отметим, что Нагибин пишет, что вся эта история - «правдивый рассказ», неизвестно только, кто действительно был другом К. Марло, похоронившим драматурга: «...по одной версии [его] звали Кеннингхемом, по другой — Корнуоллом, по третьей - Дорестом» (там же).

Однако, конечно, основное содержание новеллы - всего лишь художественный вымысел, лишь отчасти совпадающий с немногочисленными историческими фактами биографии Марло. Даже дата разыгравшейся трагедии указана не верно. Согласно официальному отчету о расследовании, Марло был убит 30 мая 1593 г., а не 1 июня, как указано у Нагибина. Возможно, писатель по какой-то причине перепутал дату смерти с днем похорон, воспользовавшись недостоверными источниками. Имя убийцы — тоже художественная выдумка автора. Из отчета, впервые полностью опубликованного в 1925 г., следует, что убийцу звали Инграмом Фризером (Ingram Frizer). Но, как известно, многие исследователи ставят под сомнение достоверность официальной версии. Наконец, никакого надгробия Марло не сохранилось, поскольку похоронили его, скорее всего, в безымянной могиле. Существует только табличка с указанием примерного места захоронения.

В фантастической повести «Дело об архиве Уильяма Шекспира» (2002) А. А. Калугина (род. 1963) Марло упоминается несколько раз, но лишь вскользь. Никаких оценок творчеству Марло писатель не дает. Главный герой повести инспектор Шелуденко, эксперт Отдела искусств в области шекспироведения, указывает только, что Шекспир играл в постановках пьес Марло. Отметим также, что в уста главного героя инспектора Шелуденко автор вкладывает следующую мысль: «Ни Кристофер Марло, ни граф Рэтланд, ни Фрэнсис Бэкон, ни Роберт Сесил, ни святые отцы иезуиты и даже ни сама Елизавета Тюдор - никто из вышеназванных людей, включая еще порядка сотни имен, в совокупности с теми, которые, как я думаю, вы тоже готовы назвать, не 
имеют никакого отношения к творчеству Шекспира! Все пьесы Шекспира написаны самим Уильямом Шекспиром, сыном перчаточника из Стратфордана-Эйвоне, городка, где говорили на диалекте, распространенном в графстве Уорвик, который с трудом понимали в других районах Англии, человеком, не знавшим ни одного иностранного языка и никуда дальше Лондона не ездившим. Быть может, в это трудно поверить, но именно так оно и было!» (Калугин, 2006: 32-33).

На страницах детектива «Шарада Шекспира» (2007) Н. А. Солнцевой обыгрывается мотив загадочной гибели Марло. Главная героиня попадает на спектакль в театр «Нео-Глобус» и знакомится с актером, который выступает под псевдонимом Кристофер Марло. И в реальной жизни он продолжает жить под маской Марло, часто говорит о том, что его ждет гибель: «Ева пришла в замешательство. Выходит, актер ничего не придумывал, и, судя по историческим данным, его вскорости на самом деле ждала гибель. Но! Нынче не конец шестнадцатого века, а начало двадцать первого; Россия не Англия, а Дептфорд - не Москва. Все кануло в Лету! И Кристофер Марло на поверку окажется каким-нибудь Колей Сидоровым, большим оригиналом, любителем веселых розыгрышей» (Солнцева, 2008: 90). В итоге по законам жанра так и происходит: Марло («обыкновенный московский парень Костя Марченко») погибает «в результате ссоры по поводу счета за ужин, ножом в голову» (там же: 156).

В 2019 г. в журнале «Знамя» была опубликована повесть Б. А. Голлера (род. 1931; наст. фамилия - Шмерович) «Мастерская Шекспира» (Голлер, 2019ab). Автор указал датировку создания: июнь - ноябрь 2018 г. Повесть также была опубликована в 2019 г. в издательстве «Геликон Плюс» (Голлер, 2019c). Это произведение - очередная версия «литературной биографии Шекспира», которая повествует о том, как еще юный житель Стратфорда приехал покорять Лондон.

В аннотации находим следующую информацию: «Шекспир, несмотря на долгую и роскошную славу (400 лет!), до сих пор мало понят как писатель. А как человек и вовсе неизвестен. Несмотря на изобилие биографий. В итоге, в массовом сознании произошло отделение Шекспира-художника от Шекспирачеловека. И где они по отношению друг к другу? Автор попытался уяснить эту связь. На основе фактов, почерпнутых в хрониках и биографиях Шекспира, сознавая, что часть фактов может быть вымышлена. На фундаменте русских переводов, ибо речь идет не просто о Шекспире, но о русском Шекспире, о нашем понимании его» (там же $\left.{ }^{5}\right)$.

По словам писателя, он опирался на шекспировские биографии М. М. Морозова, А. А. Смирнова, А. А. Аникста, И. О. Шайтанова, П. Акрой-

\footnotetext{
${ }^{5}$ Цит. по электронной версии.
} 
да и С. Шенбаума: «Ряд эпизодов повести, конечно, мог быть разработан лишь благодаря этим биографиям, а другой ряд, естественно, — плод дозволенного авторского воображения» (там же).

На страницах повести можно встретить и К. Марло, причем его фигура играет в развитии действия довольно значительную роль. Едва ли предложенный сюжет может претендовать на какую-то оригинальность. Нечто подобное мы можем наблюдать в том же известном фильме «Влюбленный Шекспир» (см., например: Гайдин, 2014).

Как отметила в небольшой рецензии в «Литературной газете» С. М. Кулешова, «после прочтения повести Бориса Голлера "Мастерская Шекспира" для сомнений (в авторстве. - Б. Г.) не остается места - настолько живой и убедительный образ главного героя создал автор. Голлеру удалось передать характер легендарного сочинителя пьес елизаветинского Возрождения так, что он стал понятным и близким читателю» (Кулешова, 2020: Электронный pecypc).

Чем-то эта повесть по своей стилистике напоминает новеллы Ю. О. Домбровского. Б. А. Голлер хотя и не упоминает Ю. Н. Тынянова, но, на наш взгляд, также придерживается принципа «Там, где кончается документ, там я начинаю» (Тынянов, 1966: 197), который писатель и литературовед сформулировал в 1930 г. в статье, опубликованной в сборнике «Как мы пишем» (Как мы пишем, 1930).

Интересно, что Голлер также четко указывает на свои стратфордианские убеждения: «У меня есть чувство, подобное чувству классовой ненависти, ко всем, кто считает, что Шекспира в настоящем смысле - не было, что он выдумка, был кто-то другой на месте его. <...> Обычная мысль, что гениальные пьесы могли быть сочинены простым актером театра "Слуги лорда-камергера” или “Слуги короля” или вообще актером, игравшим в театре “Глобус", выросшим в Стратфорде, сыном перчаточника (как Марло - был сыном башмачника), - такая мысль недоступна этим людям. Кажется слишком примитивной» (Голлер, 2019с; курсив источника. - Б. Г.).

\section{ЗАКЛЮЧЕНИЕ}

Таким образом, можно сделать следующие выводы:

1. В подавляющем большинстве произведений, даже там, где Марло главный герой, все равно есть хоть какие-то отсылки к Шекспиру, зачастую он также является участником действия, знакомым, соавтором или даже другом Марло. Единственное исключение - «Этот Марло» (“This Marlowe”, 2016) М. Б. Халлетт. 
2. Чаще всего использован миф о том, что Марло был агентом английских спецслужб (обычно под началом сэра Фрэнсиса Уолсингема).

3. Довольно часто упоминается миф об атеизме и богохульстве Марло, хотя все же в некоторых произведениях он прямо или косвенно опровергается.

4. Миф о нетрадиционной сексуальной ориентации драматурга получает распространение только после выхода в свет романа Э. Берджесса «Мертвец в Дептфорде» в 1993 г. (Например, он использован в повести Б. А. Голлера). В этом отношении можно вспомнить слова Эдмунда из шекспировского «Короля Лира»: “Men are as the time is", т. е. и писателям зачастую приходится для того, чтобы привлечь внимание к своим произведениям, касаться тем, которые имеют общественный резонанс.

5. Особое внимание уделяется последним дням жизни Марло, причем чаще всего скудные факты мифологизируются и обрастают выдуманными подробностями.

Подобная литература, на наш взгляд, кроме основной развлекательной функции, осуществляет трансляцию культурно-исторических мифов, поддерживая преемственность социокультурного процесса. По всей видимости, едва ли когда-нибудь будут решены все «тайны» биографии Марло. Тем не менее, нам доступны тексты Марло, которые, как и наследие других его современников, не менее интересны и достойны изучения, чем творчество Шекспира.

\section{СПИСОК ЛИТЕРАТУРЫ}

Гайдин, Б. Н. (2014) Шекспиросфера в современном кино: постановка проблемы [Электронный ресурс] // Информационный гуманитарный портал «Знание. Понимание. Умение». № 4 (июль - август). URL: http://zpu-journal. ru/e-zpu/2014/4/Gaydin_Shakespearean-Sphere-Cinema/ [архивировано в Way backMachine] (дата обращения: 10.12.2021).

Гайдин, Б. Н. (2020) Мифы о К. Марло в романе У. Г. Зиглера «Это был Марло: история трехсотлетнего секрета» // XXX Ежегодная богословская конференция Православного Свято-Тихоновского гуманитарного университета : материалы. М. : Изд-во ПСТГУ. 294 с. С. 190-192.

Голлер, Б. А. (2019а) Мастерская Шекспира : повесть // Звезда. № 4. С. 564.

Голлер, Б. А. (2019b) Мастерская Шекспира : повесть // Звезда. № 5. C. 96-163.

Голлер, Б. А. (2019c) Мастерская Шекспира : повесть. СПб. : Геликон Плюс. 331 с.

Домбровский, Ю. О. (1992) Вторая по качеству кровать // Домбровский Ю. О. Собр. соч. : в 6 т. / ред.-сост. К. Ф. Турумова-Домбровская. М. : ТЕРРА. 
T. 3: Рассказы разных лет; Новеллы о Шекспире; Приложение; Комментарии. 368 c. C. $154-188$.

Захаров, Н. В., Луков, Вл. А. (2011) Культ Шекспира: теория и всемирные масштабы // Известия Самарского научного центра РАН. Т. 13. № 2. С. 148154.

Иванов, Д. А., Макаров, В. С., Радлов, С. Д. (2018) Шекспир и «шекспиры» // Иностранная литература. № 8. С. 120-184.

Как мы пишем (1930) : [Очерки технологии лит. мастерства] : [сб.]. Л. : Изд-во писателей в Ленинграде. 215, [1] с.

Калугин, А. А. (2006) Дело об архиве Уильяма Шекспира. Новосибирск : Свиньин и сыновья. 215 с.

Кулешова, С. М. (2020) Мастерская Шекспира: Борис Голлер создал убедительный образ великого драматурга [Электронный ресурс] // Литературная газета. № 10 (6728). URL: https://lgz.ru/article/-10-6728-11-03-202/masterskayashekspira/ [архивировано в WaybackMachine] (дата обращения: 10.12.2020).

Луков, Вл. А., Захаров, Н. В. (2008) Культ Шекспира // Знание. Понимание. Умение. № 1. С. 132-141.

Нагибин, Ю. М. (1983) Надгробье Кристофера Марло // Нагибин Ю. М. Царскосельское утро : повести, рассказы. М. : Советский писатель. 528 с. C. 216-228.

Рябова, А. А., Жаткин, Д. Н. (2014) Кристофер Марло и русская литература второй половины XX - начала XXI в. // Известия высших учебных заведений. Поволжский регион. Гуманитарные науки. № 4 (32). С. 125-139.

Смыслова, Е. В. (2020) Образ Кристофера Марло в романе Э. Бёрджесса «Мертвец в Дептфорде» // Филологические науки. Вопросы теории и практики. Т. 13. № 2. С. 73-79. DOI: 10.30853/filnauki.2020.2.15

Солнцева, Н. А. (2008) Шарада Шекспира : роман. М. : Эксмо. 384 с.

Тынянов, Ю. Н. (1966) Как мы пишем // Юрий Тынянов. Писатель и ученый : воспоминания, размышления, встречи. М. : Молодая гвардия. 224 с. С. 193-201. («Жизнь замечательных людей». Серия биографий. Вып. 11 (426)).

Lom, H. (1978) Enter a spy: The double life of Christopher Marlowe. L. : Merlin Press. $\mathrm{x}, 112 \mathrm{p}$.

Дата поступления: 15.12.2020 2.

\section{REFERENCES}

Gaydin, B. N. (2014) Shekspirosfera v sovremennom kino: postanovka problemy [The Shakespearean sphere in contemporary cinema: The problem definition]. Informatsionnyi gumanitarnyi portal "Znanie. Ponimanie. Umenie", no. 4 (July - 
August). [online] Available at: http://zpu-journal.ru/e-zpu/2014/4/Gaydin Shakespearean-Sphere-Cinema/ [archived in WaybackMachine] (accessed 10.12.2021).

Gaydin, B. N. (2020) Mify o K. Marlo v romane U. G. Ziglera «Eto byl Marlo: istoriia trekhsotletnego sekreta» [Myths about C. Marlowe in the novel "It Was Marlowe: A Story of the Secret of Three Centuries" by W. G. Zeigler]. In: XXX Ezhegodnaia bogoslovskaia konferentsiia Pravoslavnogo Sviato-Tikhonovskogo gumanitarnogo universiteta [The 30th Annual Theological Conference of the St. Tikhon's Orthodox University] : Proceedings. Moscow : PSTGU Publ. 294 p. Pp. 190-192. (In Russ.).

Goller, B. A. (2019a) Masterskaia Shekspira [Shakespeare's workshop] : A novella. Zvezda, no. 4, pp. 5-64. (In Russ.).

Goller, B. A. (2019b) Masterskaia Shekspira [Shakespeare's workshop] : A novella. Zvezda, no. 5, pp. 96-163. (In Russ.).

Goller, B. A. (2019c) Masterskaia Shekspira [Shakespeare's workshop] : A novella. St. Petersburg : Gelikon Plius Publ. 331 p. (In Russ.).

Dombrovsky, Yu. O. (1992) Vtoraia po kachestvu krovat' [The second best bed]. In: Dombrovsky, Yu. O. Sobranie sochinenii [Collected works] : in 6 vols. I ed. and comp. by K. F. Turumova-Dombrovskaia. Moscow : TERRA Publ. Vol. 3: Rasskazy raznykh let; Novelly o Shekspire; Prilozhenie; Kommentarii [Short stories of various years; Novellas about Shakespeare; Appendix; Commentaries]. 368 p. Pp. 154-188. (In Russ.).

Zakharov, N. V. and Lukov, Vl. A. (2011) Kul't Shekspira: teoriia i vsemirnye masshtaby [The cult of Shakespeare: Theory and global scale]. Izvestiia Samarskogo nauchnogo tsentra RAN, vol. 13, no. 2, pp. 148-154. (In Russ.).

Ivanov, D. A., Makarov, V. S. and Radlov, S. D. (2018) Shekspir i «shekspiry» [Shakespeare and "shakespeares"]. Inostrannaia literatura, no. 8, pp. 120184. (In Russ.).

Kak my pishem [How we write] (1930) : [Essays on techniques of literary mastery] [A collection]. Leningrad : Izd-vo pisatelei v Leningrade [Publishing House of Writers in Leningrad]. 215, [1] p. (In Russ.).

Kalugin, A. A. (2006) Delo ob arkhive Uil'iama Shekspira [The Case of William Shakespeare's Archive]. Novosibirsk : Svin'in i synov'ia Publ. 215 p. (In Russ.).

Kuleshova, S. M. (2020) Masterskaia Shekspira: Boris Goller sozdal ubeditel'nyi obraz velikogo dramaturga [Shakespeare's workshop: Boris Goller created a convincing image of the great playwright]. Literaturnaia gazeta, no. 10 (6728). [online] Available at: https://gz.ru/article/-10-6728-11-03-202/masterskaya-shekspira/ [archived in WaybackMachine] (accessed 10.12.2020). (In Russ.).

Lukov, Vl. A. and Zakharov, N. V. (2008) Kul't Shekspira [The cult of Shakespeare]. Znanie. Ponimanie. Umenie, no. 1, pp. 132-141. (In Russ.). 
Nagibin, Yu. M. (1983) Nadgrob'e Kristofera Marlo [Gravestone of Christopher Marlowe]. In: Nagibin, Yu. M. Tsarskosel'skoe utro [A morning in Tsarskoye Selo] : novellas, short stories. Moscow : Sovetskii pisatel' Publ. 528 p. Pp. 216-228. (In Russ.).

Ryabova, A. A. and Zhatkin, D. N. (2014) Kristofer Marlo i russkaia literatura vtoroi poloviny XX - nachala XXI v. [Christopher Marlowe and Russian literature of the second half of the 20th - the early 21 st century]. Izvestiia vysshikh uchebnykh zavedenii. Povolzhskii region. Gumanitarnye nauka, no. 4 (32), pp. 125-139. (In Russ.).

Smyslova, E. V. (2020) Obraz Kristofera Marlo v romane E. Berdzhessa «Mertvets v Deptforde» [Christopher Marlowe's image in the novel "A Dead Man in Deptford" by A. Burgess]. Filologicheskie nauki. Voprosy teorii i praktiki, vol. 13, no. 2, pp. 73-79. (In Russ.). DOI: 10.30853/filnauki.2020.2.15

Solntseva, N. A. (2008) Sharada Shekspira [Shakespeare's charade] : A novel. Moscow : Eksmo Publ. 384 p. (In Russ.).

Tynyanov, Yu. N. (1966) Kak my pishem [How we write]. In: Iurii Tynianov. Pisatel' i uchenyi : vospominaniia, razmyshleniia, vstrechi [Yuri Tynyanov. Writer and scholar: Memories, reflections, meetings]. Moscow : Molodaia gvardiia Publ. 224 p. Pp. 193-201. («Zhizn' zamechatel'nykh liudei»/ Series "Life of outstanding people". Issue 11 (426)). (In Russ.).

Lom, H. (1978) Enter a spy: The double life of Christopher Marlowe. London : Merlin Press. x, 112 p.

Submission date: 15.12.2020.

Гайдин Борис Николаевич - кандидат философских наук, заведующий Лабораторией электронных научно-образовательных проектов Института фундаментальных и прикладных исследований Московского гуманитарного университета, ученый секретарь Шекспировской комиссии РАН, член-корреспондент Международной академии наук (IAS, Инсбрук). Адрес: 111395, Россия, г. Москва, ул. Юности, 5, корп. 6. Тел.: +7 (499) 374-59-30. Эл. адрес: bngaydin@mosgu.ru

GAYDIN Boris Nikolaevich, Candidate of Philosophy, Head, Laboratory of Electronic Research and Educational Projects, Institute of Fundamental and Applied Studies, Moscow University for the Humanities; Academic Secretary, Shakespeare Committee, Russian Academy of Sciences; Associate Member, International Academy of Science (IAS, Innsbruck). Postal address: Bldg. 6, 5 Yunosti St., 111395 Moscow, Russian Federation. Tel.: +7 (499) 374-59-30. E-mail: bngaydin@mosgu. $\underline{\mathrm{ru}}$ 
Для цитирования:

Гайдин Б. Н. Наследие К. Марло в художественной литературе XIX-XXI вв.: основные контексты [Электронный ресурс] // Горизонты гуманитарного знания. 2020. № 6. С. 17-31. URL: https://journals.mosgu.ru/ggz/article/view/ 1311 (дата обращения: дд.мм.гггг). DOI: 10.17805/ggz.2020.6.2 